\title{
"What is going on in the 'big tent'?" Current developments in (new) institutional theory and performance measurement and management research
}

\author{
Tobias Polzer \\ Department of Management, Institute for Organization Studies, \\ WU Vienna University of Economics and Business, Vienna, Austria
}

Developments in institutional theory and PMM

Received 12 October 2021 Revised 12 December 2021 13 January 2022 20 January 2022 Accepted 24 January 2022

\begin{abstract}
Purpose - In a recent paper that was published in Journal of Public Budgeting, Accounting and Financial Management, Modell (2021) takes stock of the institutional research on performance measurement and management (PMM) in the public sector and proposes a number of avenues for further inquiry in the area. The aim of this comment is to contextualise some of his observations against the backdrop of current developments in (new) institutional theory.

Design/methodology/approach - The recent scholarly debate about whether institutional theory needs any redirecting is the point of departure for this comment. Three of the themes from this debate are revisited and implications for research on PMM in the public sector are outlined.

Findings - First, against the backdrop of an emerging plethora of organisational forms in the public sector, this comment focusses on the locus or "where" PMM can be analysed and how organisational forms affect PMM. The second point addresses the "what" of analysis, where it is argued that PMM instruments are embedded in an ecology of concepts and a relational perspective on diffusion is introduced. A third observation is related to methodological issues and discusses the "how": how best to study manifestations of PMM systems.

Originality/value - The comment illustrates a number of implications of the current developments in (new) institutional theory for research on PMM. In so doing, the wider ambition is to stimulate an exchange between public-sector accounting and organisation studies.
\end{abstract}

Keywords Performance management, Public-sector accounting, Performance measurement, Organisational institutionalism, (new) institutional theory

Paper type Viewpoint

Much is going on in the big "institutional tent"!

(Greenwood et al., 2017, p. 1 (The “Green Handbook”))

\section{Introduction}

In his paper, Modell (2021) takes stock of (new) institutional research on performance measurement and management (PMM) in the public sector and proposes a number of avenues for further inquiry in the area. The review is an update undertaken approximately a decade after his initial assessment of the literature (Modell, 2009).

(c) Tobias Polzer. Published by Emerald Publishing Limited. This article is published under the Creative Commons Attribution (CC BY 4.0) licence. Anyone may reproduce, distribute, translate and create derivative works of this article (for both commercial and non-commercial purposes), subject to full attribution to the original publication and authors. The full terms of this licence may be seen at http:// creativecommons.org/licences/by/4.0/legalcode

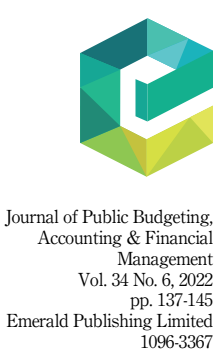

DOI 10.1108/JPBAFM-10-2021-0145 
JPBAFM 34,6

138

Regarding the assessment of extant scholarship, a central conclusion of the recent study is that "[a]lthough institutional research on PMM in the public sector has continued to grow over the past decade, much of this research still pays relatively one-sided attention to the influence of pre-existing institutions on PMM practices and has left the constitutive effects of such practices under-researched" (Modell, 2021). Regarding further research on a phenomenon that has been referred to as the "ultimate challenge" (Arnaboldi et al., 2015), the study proposes a research agenda that engages with the sociology of valuation and valuation studies (Kornberger, 2017) and an engagement with the concepts of "publicness" (Steccolini, 2019) and "organizational hybridity" (Grossi et al., 2017).

Analysing the effects of PMM "practices on the broader meaning systems that evolve in institutional fields" (Modell, 2021) is indeed a promising strategy to advance insights into the implications of the adoption of PMM systems. The sociologist Donald MacKenzie refers in this context to the "performativity" of ideas and instruments, such as PMM systems (MacKenzie, 2006). Drawing on the example of financial models and financial markets, MacKenzie suggests that models can either serve as "cameras" to faithfully reproduce what financial markets look like or "engines" to (eventually) change financial markets. With this, research on how PMM systems actually impact organisations and organisational actors (i.e. conceiving of PMM systems as an independent variable instead of a dependent one) is much needed (see also Quattrone, 2016).

Taking one step back, it needs to be noted that analysing the literature in this area of research takes place against a backdrop of a number of "moving targets":

(1) First, there have been continuous developments with respect to the research phenomenon and the empirical-instrumental focus of the PMM literature (i.e. the "what" of PMM). An example would be the rise and fall of instruments such as the Balanced Scorecard (Hoque, 2014) or digital data in management accounting (Bhimani, 2020; Quattrone, 2016) - such developments have been conceptualised by the literature as "managerial fads and fashions" (Abrahamson, 1991). Another longstanding issue is the use of performance information by organisations that is unpacked by drawing on the literature on, for instance, institutional isomorphism (e.g. recently Choi and Woo, 2021).

(2) Second, there have been changes in terms of the "where" of PMM (i.e. its locus), as "public organizational landscapes" (Leixnering et al., 2021) continue to undergo significant change, alongside the different organisational forms adopted in the public sector (Meyer and Höllerer, 2014; Meyer and Quattrone, 2021). Indeed, the diversity of the "animals in the administrative zoo" (Bach and Jann, 2010) keeps expanding.

(3) Third, there are continuous developments on the conceptual side, as Modell had already pointed out in the earlier review (Modell, 2009). On the one hand, PMM research has combined (new) institutional theory with other theories, such as actornetwork theory (inter-disciplinary perspective, e.g. Modell et al., 2017) - with the caveat that the supplementary theories have to be compatible, for example with respect to their respective assumptions in terms of phenomenology (Meyer, 2008). On the other hand, institutional theory itself has continued to change (intra-disciplinary perspective). For instance, while earlier institutional research was interested in "[w] hat makes organizations so similar?" (the opening question from DiMaggio and Powell, 1983, p. 147), i.e. the forces driving organisations in the same institutional field to resemble each other, later studies have paid attention to and emphasised aspects such as practice variation (Lounsbury, 2008), the agency of institutionally embedded agents in changing institutionalised meaning systems (Seo and Creed, 2002) and the "outcomes and consequences of institutions" (Greenwood et al., 2017, p. 1). 
The recent scholarly debate about whether institutional theory needs any redirecting (Greenwood et al., 2014; Meyer and Höllerer, 2014) - despite other claims that it has reached maturity (Scott, 2008) - is the point of departure for this comment. In the next section, three of the themes from this debate are revisited and implications for research on PMM in the public sector are outlined. The comment concludes with a number of general observations.

\section{Current topics in institutional research and their relevance to PMM research}

The locus or the "where" of analysis: an emerging plethora of organisational forms

Institutional theory is a very vibrant area in contemporary organisation studies (Greenwood et al., 2017; Meyer et al., 2021) and is therefore by definition concerned with organisations. As Brunsson and Sahlin-Andersson noted, many public-sector reforms over the past decades "can be interpreted as attempts at constructing organizations" (2000, p. 721). However, recent conceptual advances highlight that organisations have become an "increasingly unruly unit of analysis" (Meyer and Höllerer, 2014, p. 1,225). This is, as Meyer and Quattrone (2021, p. 1,377$)$ note, because,

[t]oday there is a proliferation of new organizational forms and forms of organizing that operate alongside a global and intersectoral expansion of established forms of formal organization and technologies of rationalization. They somehow mesh the emergence of the digital, the re-appearance of magical thinking, irrationalities, fragmentation and disorders.

In other words, public-sector organisational landscapes have evolved significantly over the last decades, leading to a "daunting complexity of organizational designs" (Greenwood and Miller, 2010, p. 81). Meyer and Höllerer (2014) provide a range of examples for such contemporary organisational forms, and - relevant for the public sector - refer to "network" (Kenis and Provan, 2006; Powell, 1990), "polycentric" (Ostrom, 2010), "meta” (Ahrne and Brunsson, 2005), "partial" (Ahrne and Brunsson, 2011), "hybrid" (Vakkuri et al., 2021) and "fluid" (Schreyögg and Sydow, 2010) organisational forms. The latter forms encompass recent (often project-based) forms such as "crowd-sourcing", "co-creation of value", "open government" and "open innovation" (Meyer and Höllerer, 2014).

Relevance to PMM research: From the above observations, the question for scholars is how PMM systems and practices unfold in such organisational forms beyond the "classic" form of "complete" organisations (Döhler, 2020) as the unit of analysis. Maybe of particular interest is how these organisational forms shape PMM systems and practices (PMM as dependent variable) and the interplay of PMM and organisational forms. In this sense, Modell (2021) is right to recommend a focus on organisational hybridity, as the concept can be understood as characterising "organizations that combine multiple institutional logics" (Battilana and Lee, 2014, p. 401f.) - for example, the institutional logics of "bureaucracy" and "market-capitalism" in public-private partnerships or the "bureaucracy" and "democracy" logics in "open government" projects. A recent analysis by Leixnering et al. (2021) asks how "domestic city organisations", i.e. legally independent public-sector organisations that are, however, fully owned by a polycentric public entity, are governed. The study by Ruggiero et al. (2021), although not drawing on an institutional approach, is perhaps another example, as it attempts to develop a conceptual model to study PMM in co-production settings.

\section{Ecology of concepts or the "what" of analysis: a relational perspective on the diffusion of PMM instruments}

A second observation relates to the fact that management concepts are seldom introduced in isolation but diffuse and are theorised in relation to other ideas and instruments in an institutional environment (such as an institutional field, Höllerer et al., 2020; Polzer et al., 2016). Thus, additions to PMM systems always have to be regarded in the light of existing and simultaneously introduced PMM instruments (Strang and Soule, 1998) leading to an "ecology of 
JPBAFM 34,6

140

concepts" (Abrahamson and Fairchild, 1999). In this context, Meyer and Höllerer (2014, p. 1228f) make the point that

[t]he main shortcoming of existing diffusion and translation studies has been that they underplay interrelatedness and overly decompose - that is, they are set up as if the adoption of the one structural component or practice they analyse happened in a vacuum. The configurational approach, while focussing on such interrelations, was suffering from assuming too much consistency and coherence among the different organizational elements. Such elements, we maintain, may be interlinked through all sorts of relationships: they may support or compete.

This has been recognised not only by institutional researchers that focus on the diffusion of concepts, but also by the scholarly inquiry of "calculative infrastructures" (Bowker et al., 2019). PMM systems can be seen as an example of a multi-layered "calculative infrastructure". Reilley and Scheytt's (2019) study analyses the "external quality assurance system" in German hospitals and analytically differentiates three phases of "infrastructural development", each of them adding to the PMM system. Their research shows how (1) methods for calculating quality, (2) processes and responsibilities for collecting and coordinating data and (3) programmatic reform ideals about PMM systems (such as "costeffective quality control" and "quality-based budgeting") converged with one another. In the course of their study, it is shown "that the succession of these phases represents a gradual layering process, whereby old ways of enacting quality governance are not replaced, but augmented by new sets of calculative practices, institutions and ideas" (Reilley and Scheytt, 2019, p. 43). The authors conclude that conceiving of infrastructures as "multi-layered complexes" allows researchers to explore how PMM systems construct possibilities for control, remain stable over time and, ultimately, transform (as "engines") the fields in which they are embedded. Given this, Sven Modell's (2021) call to complement institutional research on PMM with insights from valuation studies is a timely one.

Relevance to PMM research: The above insights suggest it may be useful to apply a relational perspective to the diffusion of PMM instruments. For example, what other reporting systems do PMM compete with in a given institutional environment? What existing systems work as facilitators? How are new tools theorised in relation to existing ones? Methodologically, semantic networks can be used to illustrate relationships between concepts (e.g. Polzer and Seiwald, 2021).

Instruments in a PMM system might also reflect different institutional logics (Schäffer et al., 2015) - for example, some focussing on the correct spending of public funds ("bureaucracy") while others emphasising value-for-money considerations ("market-capitalism"). Frictions are possible when instruments that convey a particular logic are integrated in one PMM system. Here, the lenses of institutional pluralism (Dunn and Jones, 2010) and complexity (Fossestøl et al., 2015; Palermo et al., 2017) might be applied to study such clashes.

\section{Methodology: how to study manifestations of PMM systems?}

A final observation relates to methodological issues. Current strands in institutional theory see "institutions as communicative accomplishments" (Meyer et al., 2018, p. 392) and Cornelissen et al. (2015, p. 10) call for researchers to put "communication front and centre in institutional theory and analysis". However, most of the institutional research on PMM in the public sector currently uses textual analysis (e.g. interviews or documents) and seldom on visual analysis (Davison, 2015; for an exception see, e.g. Parker, 2016). This is a shortcoming, as visual artefacts "can become resources for institutional dynamics when they act as communicative spaces for a continuous negotiation of institutional values and social orders" (Quattrone et al., 2021).

Current institutional scholarship conceives of institutions as multimodal accomplishments (Jancsary et al., 2017; Jones et al., 2017). In this context, the recent paper by Ronzani and Gatzweiler (2021) on PMM in an infrastructure megaproject explains that 
multimodality scholars "seek to explore the interaction of multiple sign systems in generating meaning in organizations [...][and] emphasize how meaning is a supra-individual construct accomplished through multiple modes of communication (e.g. text and visuals)". These modes of communication are, in turn, "socially shaped and culturally given semiotic resource [s] for making meaning" (Kress, 2009, p. 79). Similarly, in the (general) accounting literature, Beattie (2014) refers to studies that focus on communication as following the "narrative" turn. The term "narrative" here refers "to words (e.g. chronicles, emplotted stories and interview transcripts) and can include pictures and other visuals" (Beattie, 2014, p. 112).

Relevance to PMM research: Quattrone et al.'s (2021) point on the role of visual artefacts as communicative spaces is of particular relevance when looking at the organisational effects of PMM systems and practices. PMM research could, for instance, investigate the performativity of visual artefacts such as performance dashboards (see Allain et al., 2021 for an example) in combination with how organisational actors make sense of and explain certain results, for example underperformance. However, a boundary condition for such research is that performativity is conditioned by (pre-existing) institutions and (embedded) agency involved in reproducing and transforming PMM practices (Baker and Modell, 2019). Here, Modell (2021) makes the important point that without considering the institutional embeddedness of actors and processes, institutional research on PMM loses much of its distinctive identity.

Another fruitful avenue for analysis could be how visual representation is used in attempts to legitimise PMM systems (Jones et al., 2017). In this context, Höllerer et al. (2013) found that visual artefacts are able to connect divergent elements (such as financial and nonfinancial performance indicators on a dashboard) and are thus suited to increasing the comprehensibility and familiarity that are required to create "legitimacy spillovers".

\section{Conclusion}

The comment concludes with two remarks. The first one relates to the research phenomenon "PMM in the public sector". Performance means different things to different people (De Waele et al., 2021), and Boyne (2002, p. 101) noted in his seminal piece on the differences between private- and public-sector management that as "the goals of public organizations are more vague than those of their private counterparts [ ...], performance targets are inherently unclear, and [...] private sector techniques such as management by objectives are likely to be inappropriate". Drawing on the concepts of "publicness" (e.g. Steccolini, 2019) and "valuation studies" (e.g. Kornberger, 2017) might indeed help to sharpen the understanding of the research phenomenon itself and its multifaceted nature.

A second observation is that academic disciplines do not always recognise and acknowledge the insights that neighbouring disciplines have produced. Despite focussing on similar topics and utilising the same conceptual backgrounds, research produced in the overlap between disciplines is at times "still like ships that pass in the night" (Andrews and Esteve, 2015; see also Davies et al., 2018). For example, the long-established research interest of organisational scholars in commensuration in the form of university rankings (Espeland and Sauder, 2007; Espeland and Stevens, 1998; Ringel et al., 2021) could resonate productively with research produced by public-sector accounting scholars that focusses on PMM in universities (Kallio et al., 2017, 2021).

Given this situation, producing institutional research on PMM systems in the public sector that resonates with the current debates in institutional theory and public administration could be a useful remedy. Therefore, Sven Modell's suggestions (Modell, 2021) to link PMM research to current "hot topics" in institutional theory such as hybrid organisations and hybrid organising seems to be a promising avenue (for recent developments see the recent volume of Research in the Sociology of Organizations, eds. Besharov and Mitzinneck, 2021). The recent
Developments in institutional theory and PMM 
JPBAFM 34,6

symposium in Public Administration curated by Steccolini et al. (2020) that included a study based on the concept of institutional isomorphism (George et al., 2020) can also be seen as one such attempt by the public-sector accounting community to reach out to those researching in the area of wider public administration.

\section{References}

Abrahamson, E. (1991), "Managerial fads and fashions: the diffusion and rejection of innovations", The Academy of Management Review, Vol. 16 No. 3, pp. 586-612.

Abrahamson, E. and Fairchild, G. (1999), "Management fashion: lifecycles, triggers, and collective learning processes”, Administrative Science Quarterly, Vol. 44 No. 4, pp. 708-740.

Ahrne, G. and Brunsson, N. (2005), "Organizations and meta-organizations", Scandinavian Journal of Management, Vol. 21, pp. 429-449.

Ahrne, G. and Brunsson, N. (2011), "Organization outside organizations: the significance of partial organization”, Organization, Vol. 18 No. 1, pp. 83-104.

Allain, E., Lemaire, C. and Lux, G. (2021), "Visual boards as a medium for a relational-based approach", in Hoque, Z. (Ed.), Public Sector Reform and Performance Management in Developed Economies: Outcomes-Based Approaches in Practice, Routledge, New York, pp. 362-376.

Andrews, R. and Esteve, M. (2015), "Still like ships that pass in the night? The relationship between public administration and management studies", International Public Management Journal, Vol. 18 No. 1, pp. 31-60.

Arnaboldi, M., Lapsley, I. and Steccolini, I. (2015), "Performance management in the public sector: the ultimate challenge", Financial Accountability and Management, Vol. 31 No. 1, pp. 1-22.

Bach, T. and Jann, W. (2010), "Animals in the administrative zoo: organizational change and agency autonomy in Germany", International Review of Administrative Sciences, Vol. 76 No. 3, pp. 443-468.

Baker, M. and Modell, S. (2019), "Rethinking performativity: a critical realist analysis of accounting for corporate social responsibility", Accounting, Auditing and Accountability Journal, Vol. 32 No. 4, pp. 930-956.

Battilana, J. and Lee, M. (2014), “Advancing research on hybrid organizing. Insights from the study of social enterprises", Academy of Management Annals, Vol. 8 No. 1, pp. 397-441.

Beattie, V. (2014), "Accounting narratives and the narrative turn in accounting research: issues, theory, methodology, methods and a research framework", British Accounting Review, Vol. 46, pp. 111-134.

Besharov, M.L. and Mitzinneck, B.C. (2021), "Heterogeneity in organizational hybridity: a configurational, situated and dynamic approach", Research in the Sociology of Organizations, Vol. 69 No. 1, pp. 3-25.

Bhimani, A. (2020), "Digital data and management accounting: why we need to rethink research methods", Journal of Management Control, Vol. 31 Nos 1-2, pp. 9-23.

Bowker, G.C., Elyachar, J., Kornberger, M., Mennicken, A., Miller, P., Nucho, J.R. and Pollock, N. (2019), "Introduction to thinking infrastructures", Research in the Sociology of Organizations, Vol. 62 No. 1, pp. 1-13.

Boyne, G.A. (2002), "Public and private management: what's the difference?”, Journal of Management Studies, Vol. 39 No. 1, pp. 97-122.

Brunsson, N. and Sahlin-Andersson, K. (2000), "Constructing organizations: the example of public sector reform", Organization Studies, Vol. 21 No. 4, pp. 721-746.

Choi, Y. and Woo, H. (2021), "Understanding diverse types of performance information use: evidence from an institutional isomorphism perspective", Public Management Review, pp. 1-20, doi: 10. 1080/14719037.2021.1955953.

Cornelissen, J.P., Durand, R., Fiss, P.C., Lammers, J.C. and Vaara, E. (2015), "Putting communication front and center in institutional theory and analysis", Academy of Management Review, Vol. 40 No. 1, pp. 10-27. 
Davies, A., Manning, S. and Söderlund, J. (2018), "When neighboring disciplines fail to learn from each other: the case of innovation and project management research", Research Policy, Vol. 47 No. 5, pp. 965-979.

Davison, J. (2015), "Visualising accounting: an interdisciplinary review and synthesis", Accounting and Business Research, Vol. 45 No. 2, pp. 121-165.

De Waele, L., Polzer, T., van Witteloostuijn, A. and Berghman, L. (2021), “'A little bit of everything?' Conceptualising performance measurement in hybrid public sector organisations through a literature review", Journal of Public Budgeting, Accounting and Financial Management, Vol. 33 No. 3, pp. 343-363.

DiMaggio, P.J. and Powell, W.W. (1983), "The iron cage revisited. Institutional isomorphism and collective rationality in organizational fields", American Sociological Review, Vol. 48 No. 2, pp. 147-160.

Döhler, M. (2020), "The architecture of organizations as missed opportunity in political research", Public Administration, Vol. 98 No. 4, pp. 891-904.

Dunn, M.B. and Jones, C. (2010), "Institutional logics and institutional pluralism. The contestation of care and science logics in medical education, 1967-2005”, Administrative Science Quarterly, Vol. 55, pp. 114-149.

Espeland, W.N. and Sauder, M. (2007), "Rankings and reactivity: how public measures recreate social worlds", American Journal of Sociology, Vol. 113 No. 1, pp. 1-40.

Espeland, W.N. and Stevens, M.L. (1998), "Commensuration as a social process", Annual Review of Sociology, Vol. 24 No. 1, pp. 313-343.

Fossestøl, K., Breit, E., Andreassen, T.A. and Klemsdal, L. (2015), "Managing institutional complexity in public sector reform: hybridization in front-line service organizations", Public Administration, Vol. 93 No. 2, pp. 290-306.

George, B., Baekgaard, M., Decramer, A., Audenaert, M. and Goeminne, S. (2020), "Institutional isomorphism, negativity bias and performance information use by politicians: a survey experiment”, Public Administration, Vol. 98 No. 1, pp. 14-28.

Greenwood, R. and Miller, D. (2010), "Tackling design anew: getting back to the heart of organization theory," Academy of Management Perspectives, Vol. 24, pp. 78-88.

Greenwood, R., Hinings, C.R. and Whetten, D. (2014), "Rethinking institutions and organizations", Journal of Management Studies, Vol. 51 No. 7, pp. 1206-1220.

Greenwood, R., Oliver, C., Lawrence, T.B. and Meyer, R.E. (2017), "Introduction: into the fourth decade", in Greenwood, R., Oliver, C., Lawrence, T.B. and Meyer, R.E. (Eds), The SAGE Handbook of Organizational Institutionalism, Sage, Los Angeles, pp. 1-23.

Grossi, G., Reichard, C., Thomasson, A. and Vakkuri, J. (2017), "Editorial. Theme: performance measurement of hybrid organizations-emerging issues and future research perspectives", Public Money and Management, Vol. 37 No. 6, pp. 379-386.

Höllerer, M.A., Jancsary, D., Meyer, R.E. and Vettori, O. (2013), "Imageries of corporate social responsibility: visual recontextualization and field-level meaning", Research in the Sociology of Organizations, Vol. 39B, pp. 139-174.

Höllerer, M.A., Jancsary, D., Barberio, V. and Meyer, R.E. (2020), "The interlinking theorization of management concepts: cohesion and semantic equivalence in management knowledge", Organization Studies, Vol. 41 No. 9, pp. 1284-1310.

Hoque, Z. (2014), "20 Years of studies on the balanced scorecard: trends, accomplishments, gaps and opportunities for future research", The British Accounting Review, Vol. 46 No. 1, pp. 33-59.

Jancsary, D., Meyer, R.E., Höllerer, M.A. and Boxenbaum, E. (2017), "Institutions as multimodal accomplishments: towards the analysis of visual registers", Research in the Sociology of Organizations, Vol. 54A No. 1, pp. 87-117.

Jones, C., Meyer, R.E., Jancsary, D. and Höllerer, M.A. (2017), "The material and visual basis of institutions", in Greenwood, R., Oliver, C., Lawrence, T.B. and Meyer, R.E. (Eds), The SAGE Handbook of Organizational Institutionalism, Sage, Los Angeles, pp. 621-646.

Developments in institutional theory and PMM 
JPBAFM 34,6

144

Kallio, K.-M., Kallio, T.J. and Grossi, G. (2017), "Performance measurement in universities: ambiguities in the use of quality versus quantity in performance indicators", Public Money and Management, Vol. 37 No. 4, pp. 293-300.

Kallio, K.-M., Kallio, T.J., Grossi, G. and Engblom, J. (2021), "Institutional logic and scholars' reactions to performance measurement in universities", Accounting, Auditing and Accountability Journal, Vol. 34 No. 9, pp. 104-130.

Kenis, P. and Provan, K.G. (2006), "The control of public networks", International Public Management Journal, Vol. 9 No. 3, pp. 227-247.

Kornberger, M. (2017), "The values of strategy: valuation practices, rivalry and strategic agency", Organization Studies, Vol. 38 No. 12, pp. 1753-1773.

Kress, G. (2009), Multimodality: Exploring Contemporary Methods of Communication, Routledge, New York.

Leixnering, S., Meyer, R.E. and Polzer, T. (2021), "Hybrid coordination of city organisations: the rule of people and culture in the shadow of structures", Urban Studies, Vol. 58 No. 14, pp. 2933-2951.

Lounsbury, M. (2008), "Institutional rationality and practice variation: new directions in the institutional analysis of practice", Accounting, Organizations and Society, Vol. 33 Nos 4-5, pp. 349-361.

MacKenzie, D. (2006), An Engine, Not a Camera. How Financial Models Shape Markets, MIT Press, Cambridge, MA and London.

Meyer, R.E. (2008), "New sociology of knowledge: historical legacy and contributions to current debates in institutional research", in Greenwood, R., Oliver, C., Sahlin, K. and Suddaby, R. (Eds), The SAGE Handbook of Organizational Institutionalism, Sage, London, pp. 519-538.

Meyer, R.E. and Höllerer, M.A. (2014), "Does institutional theory need redirecting?", Journal of Management Studies, Vol. 51 No. 7, pp. 1221-1233.

Meyer, R.E. and Quattrone, P. (2021), "Living in a post-truth world? Research, doubt and organization studies”, Organization Studies, Vol. 42 No. 9, pp. 1373-1383.

Meyer, R.E., Jancsary, D., Höllerer, M.A. and Boxenbaum, E. (2018), “The role of verbal and visual text in the process of institutionalization", Academy of Management Review, Vol. 43 No. 3, pp. 392-418.

Meyer, R.E., Jancsary, D. and Höllerer, M.A. (2021), "Neoinstitutional theory and nonprofit governance research", in Donnelly-Cox, G., Meyer, M. and Wijkström, F. (Eds), Research Handbook on Nonprofit Governance, Edward Elgar, Cheltenham and Northampton, pp. 141-164.

Modell, S. (2009), "Institutional research on performance measurement and management in the public sector accounting literature: a review and assessment”, Financial Accountability and Management, Vol. 25 No. 3, pp. 277-303.

Modell, S. (2021), "New developments in institutional research on performance measurement and management in the public sector", Journal of Public Budgeting, Accounting and Financial Management, pp. 1-17, doi: 10.1108/JPBAFM-04-2021-0070.

Modell, S., Vinnari, E. and Lukka, K. (2017), "On the virtues and vices of combining theories: the case of institutional and actor-network theories in accounting research", Accounting, Organizations and Society, Vol. 60, pp. 62-78.

Ostrom, E. (2010), "Beyond markets and states: polycentric governance of complex economic systems", American Economic Review, Vol. 100 No. 3, pp. 641-672.

Palermo, T., Power, M. and Ashby, S. (2017), "Navigating institutional complexity: the production of risk culture in the financial sector", Journal of Management Studies, Vol. 54 No. 2, pp. 154-181.

Parker, L.D. (2016), "From scientific to activity based office management: a mirage of change", Journal of Accounting and Organizational Change, Vol. 12 No. 2, pp. 177-202.

Polzer, T. and Seiwald, J. (2021), "Outcome orientation in Austria: how far can late adopters move?", in Hoque, Z. (Ed.), Public Sector Reform and Performance Management in Developed Economies: Outcomes-Based Approaches in Practice, Routledge, London, pp. 119-145. 
Polzer, T., Meyer, R.E., Höllerer, M.A. and Seiwald, J. (2016), "Institutional hybridity in public sector reform: replacement, blending, or layering of administrative paradigms", Research in the Sociology of Organizations, Vol. 48B No. 1, pp. 69-99.

Powell, W.W. (1990), "Neither market nor hierarchy. Network forms of organization", Research in Organizational Behavior, Vol. 12 No. 1, pp. 295-336.

Quattrone, P. (2016), "Management accounting goes digital: will the move make it wiser?", Management Accounting Research, Vol. 31 No. 1, pp. 118-122.

Quattrone, P., Ronzani, M., Jancsary, D. and Höllerer, M.A. (2021), "Beyond the visible, the material and the performative: shifting perspectives on the visual in organization studies", Organization Studies, Vol. 42 No. 8, pp. 1197-1218.

Reilley, J. and Scheytt, T. (2019), "A calculative infrastructure in the making: the emergence of a multilayered complex for governing healthcare”, Research in the Sociology of Organizations, Vol. 62 No. 1, pp. 43-68.

Ringel, L., Espeland, W., Sauder, M. and Werron, T. (2021), "Worlds of rankings", Research in the Sociology of Organizations, Vol. 74 No. 1, pp. 1-23.

Ronzani, M. and Gatzweiler, M.K. (2021), "The lure of the visual: multimodality, simplification, and performance measurement visualizations in a megaproject", Accounting, Organizations and Society, pp. 1-19, doi: 10.1016/j.aos.2021.101296.

Ruggiero, P., Sorrentino, D. and Mussari, R. (2021), "Performance measurement and management in co-production: an explorative analysis", in Hoque, Z. (Ed.), Public Sector Reform and Performance Management in Developed Economies: Outcomes-Based Approaches in Practice, Routledge, New York, pp. 219-247.

Schäffer, U., Strauss, E. and Zecher, C. (2015), "The role of management control systems in situations of institutional complexity", Qualitative Research in Accounting and Management, Vol. 12 No. 4, pp. 395-424.

Schreyögg, G. and Sydow, J. (2010), "Organizing for fluidity? Dilemmas of new organizational forms", Organization Science, Vol. 21, pp. 1251-1262.

Scott, W.R. (2008), “Approaching adulthood: the maturing of institutional theory”, Theory and Society, Vol. 37 No. 5, pp. 427-442.

Seo, M.-G. and Creed, W.E.D. (2002), "Institutional contradictions, praxis, and institutional change: a dialectical perspective", Academy of Management Review, Vol. 27 No. 2, pp. 222-247.

Steccolini, I. (2019), "Accounting and the post-new public management: Re-considering publicness in accounting research", Accounting, Auditing and Accountability Journal, Vol. 32 No. 1, pp. 255-279.

Steccolini, I., Saliterer, I. and Guthrie, J. (2020), "The role(s) of accounting and performance measurement systems in contemporary public administration", Public Administration, Vol. 98 No. 1, pp. 3-13.

Strang, D. and Soule, S.A. (1998), "Diffusion in organizations and social movements: from hybrid corn to poison pills", Annual Review of Sociology, Vol. 24 No. 1, pp. 265-290.

Vakkuri, J., Johanson, J.E. and Rajala, T. (2021), "A shotgun marriage? Performance management in the hybridized government", in Holzer, M. and Ballard, A. (Eds), The Public Productivity and Performance Handbook, Routledge, New York.

\section{Corresponding author}

Tobias Polzer can be contacted at: tobias.polzer@wu.ac.at

For instructions on how to order reprints of this article, please visit our website:

www.emeraldgrouppublishing.com/licensing/reprints.htm

Or contact us for further details: permissions@emeraldinsight.com
Developments in institutional theory and PMM 